\title{
製造条件の異なるスパゲティの機械的性質の調査
}

\author{
酒井 孝 $^{1, \dagger}$ ，長沼 陽介 $^{2}$ \\ 1 成蹊大学理工学部, ${ }^{2}$ 成蹊大学大学院理工学研究科
}

\section{Material Properties for Spaghetti with Different Product Conditions}

\author{
Takashi SAKAI $^{1, \dagger}$, Yosuke NAGANUMA $^{2}$ \\ ${ }^{1}$ Faculty of Science and Technology, Seikei University, 3-3-1 Kichijoji-Kitamachi, Musashino, Tokyo 180-8633, Japan \\ ${ }^{2}$ Graduate School of Science and Technology, Seikei University, \\ 3-3-1 Kichijoji-Kitamachi, Musashino, Tokyo 180-8633, Japan
}

\begin{abstract}
The quality of spaghetti, given the same raw materials, will vary depending on the extrusion rate, pressure, and drying conditions during manufacture and at the time of opening of the package. In this study of spaghetti of several types produced with different manufacturing conditions, mechanical properties were ascertained using the compression test to identify the factors that influence spaghetti quality. Furthermore, characteristics of ordinary dry spaghetti and raw spaghetti, which is said to provide excellent taste, produced in a research laboratory are compared to assess the differences of food textures quantitatively. Identification of these factors is expected to improve the food texture of spaghetti.
\end{abstract}

Keywords: spaghetti, mechanical property, compression test, water content ratio, microstructure

\section{1. 緒言}

スパゲティは一般的にデュラムセモリナ粉と水のみ を原料として，押出し成形加工で製造されている．原 料をこれらで一定としたとき，スパゲティの品質を決 定する要因として，製造時に打ける押出し速度や圧力， 乾燥条件，さらには製品パッケージの開封期間などが 挙げられる。茹でる前のスパゲティの品質は，茹でた 後のスパゲティの食感に影響を及ぼすことが報告され ているが [1]，その詳細は明らかになっていない。

一方，スパゲティ麺の機械的性質を調査する方法と して，引張試験や圧縮試験が考えられる。これまでに， 麺の引張試験として，素麺 [2] やうどん [3] に対する報 告がある。引張試験では麺の断面全体に対して均一に 引張荷重が負荷される。したがって，アルデンテの特 徵を有する茹で後のスパゲティに対して引張試験を行 うと，外表面の粘弾性特性 [4] を示す部位と，中心部の 脆性的な芯の特性とが混交した機械的性質を示すこと になる。その一方で押し込みプランジャーを用いた圧

(受付 2014 年 8 月 26 日, 受理 2014 年 11 月 18 日)

1 ₹180-8633 東京都武蔵野市吉祥寺北町3-3-1

2 于 180-8633 東京都武蔵野市吉祥寺北町3-3-1

FAX: 0422-37-3712, E-mail: sakai@st.seikei.ac.jp
縮試験を行った場合は，外表面と芯の特性が，圧縮変 位の量に対応した結果から表される。この点から，茹 で後のスパゲティの機械的性質を評価する方法として は圧縮試験が適切である.

そこで本報では，製造条件の異なる数種類のスパゲ ティを対象として，プランジャーを用いた圧縮試験か ら得られた機械的性質の観点から，茹でた後の特性值 の違いを実験的に調査した。また，乾燥スパゲティと 生スパゲティの機械的な特性值を，含水率や電子顕微 鏡による表面観察結果と総合して評価し，スパゲティ の品質に影響を与える因子について明らかにした。今 回のこれらの調査結果は，今後のスパゲティ湎の食感 向上に設計指針として役立つと考えられる。

\section{2. 供試材および実験方法}

\section{1 供試材}

開封時期の異なる 2 種類の市販の乾燥スパゲティ D-1，D-2，打よび研究室内で製造した押出し条件の異 なる 4 種類の生スパゲティ $\mathrm{R}-1, \mathrm{R}-2, \mathrm{R}-3, \mathrm{R}-4$ の, 計 6 種類を供試材とした. Table 1 に各供試材の条件を 示す。開封時期の異なる供試材については，日清フー ズ株)製マ・マースパゲティ $1.6 \mathrm{~mm}$ の乾燥スパゲティの 開封時期を変化させ，開封直後のもの D-1 と開封から 
Table 1 Numerical list of materials condition.

\begin{tabular}{c|c|c|c|c}
\hline & $\begin{array}{c}\text { Specimen } \\
\text { number }\end{array}$ & $\begin{array}{c}\text { Opening } \\
\text { period (month) }\end{array}$ & $\begin{array}{c}\text { Extrusion } \\
\text { die (hole) }\end{array}$ & $\begin{array}{c}\text { Diameter } \\
(\mathrm{mm})\end{array}$ \\
\hline \multirow{2}{*}{$\begin{array}{c}\text { Dry } \\
\text { spaghetti }\end{array}$} & $\mathrm{D}-1$ & 0 & - & \multirow{2}{*}{1.60} \\
\cline { 2 - 2 } & $\mathrm{D}-2$ & 16 & & \\
\hline \multirow{3}{*}{$\begin{array}{c}\text { Raw } \\
\text { spaghetti }\end{array}$} & $\mathrm{R}-1$ & & $28(\mathrm{All})$ & \multirow{2}{*}{1.75} \\
\cline { 2 - 2 } & $\mathrm{R}-2$ & \multirow{2}{*}{$(0)$} & $21(3 / 4)$ & \multirow{2}{*}{} \\
\cline { 2 - 2 } & $\mathrm{R}-3$ & & $14(1 / 2)$ & \\
\cline { 2 - 2 } & $\mathrm{R}-4$ & & $7(1 / 4)$ & \\
\hline
\end{tabular}

16 ヶ月経過したもの D-2 を供試材とした。乾燥スパゲ ティは保存環境条件によって状態が変化するため，年 間を通じて約 $20 \%$ の一定に湿度を保つアズワン(株)製の オートドライデシケータ内で常に保管した。このオー トドライデシケータを $23^{\circ} \mathrm{C} て ゙$ 温度を一定に保っている 電子顕微鏡室に設置して温度管理した。研究室内での 押出し条件の異なる供試材の製造については, Fig. 1 に 示す(有) mercato italiano 社製のパスタマシン (MAGICA) を用いた。 日本製粉(株)社製のデュラムセモリナ粉 (ジョーカーA） $1 \mathrm{~kg}$ と軟水のミネラルウォーター（ア サヒ飲料・六甲のおいしい水） $280 \mathrm{~g}$ を同機で自動混 練し，同図 (b) および (c) に示した直径 $1.75 \mathrm{~mm}$ のスパ ゲティダイスの孔数を変化させて押出しを行った。 ダ

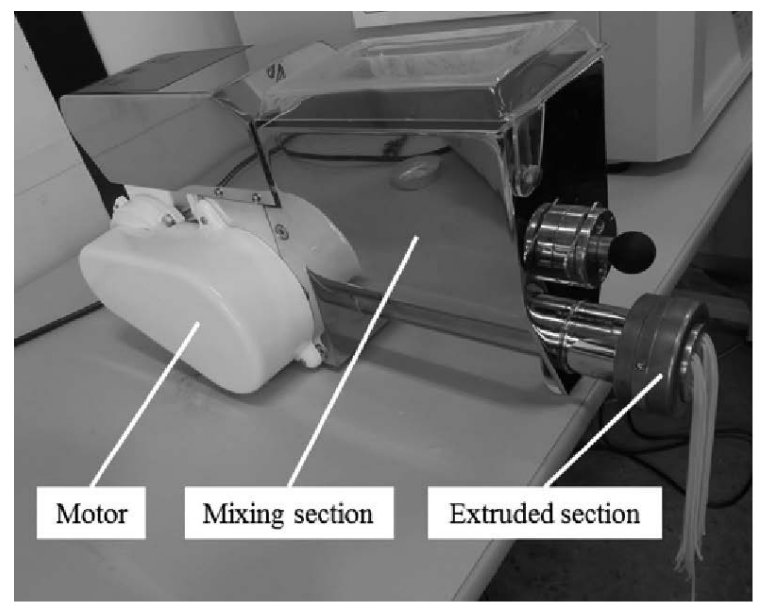

(a) Overview of machine

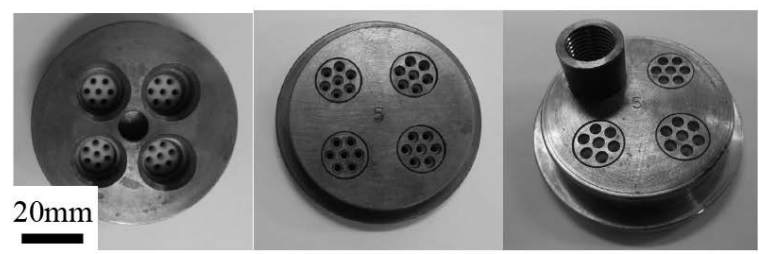

(b) Inside of die (c) Outside of die (d) Outside of die with sensor hole

Fig. 1 Overview of the pasta machine (MAGICA).
イスの孔数を変化させて押出しを行うことで，押出し 圧力や押出速度の異なる生スパゲティの供試材を作製 した。

押出し速度 $v$ の測定はスパゲティの押出しを通常の 28 孔 (R-1) と, 孔を治具とテープで塞いだ 21 孔 $(\mathrm{R}-2)$, 14 孔（R-3)，7 孔（R-4）のダイスでそれぞれ行い, 一般的なスパゲティの長さ $300 \mathrm{~mm}$ に達するまでのよ うすをデジタルカメラで撮影し, 各経過時間 $\Delta t$ を式 (1)

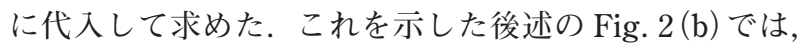
困の横軸はビデオ撮像の経過時間（押出し実験の全時 間経過）とし，横軸の 0 点はダイスから生地が出た瞬 間と定義している.

$$
v=\frac{300}{\Delta t}
$$

押出し圧力の測定は，スパゲティダイスに取付け用の 孔を機械加工し，日本ダイニスコ(株)社製の樹脂圧力七 ンサ（NP463-1/2-35MPA-15/45-J）を装着することで，

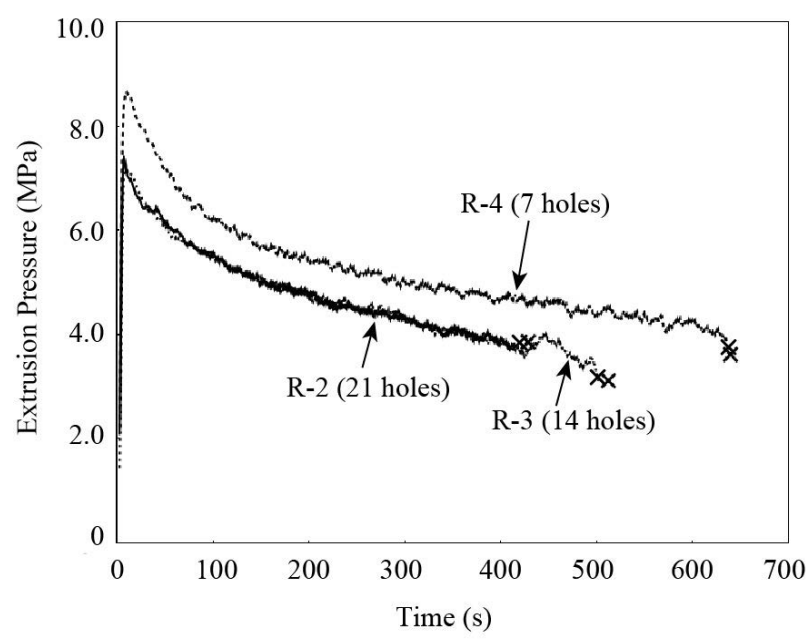

(a) Extrusion force

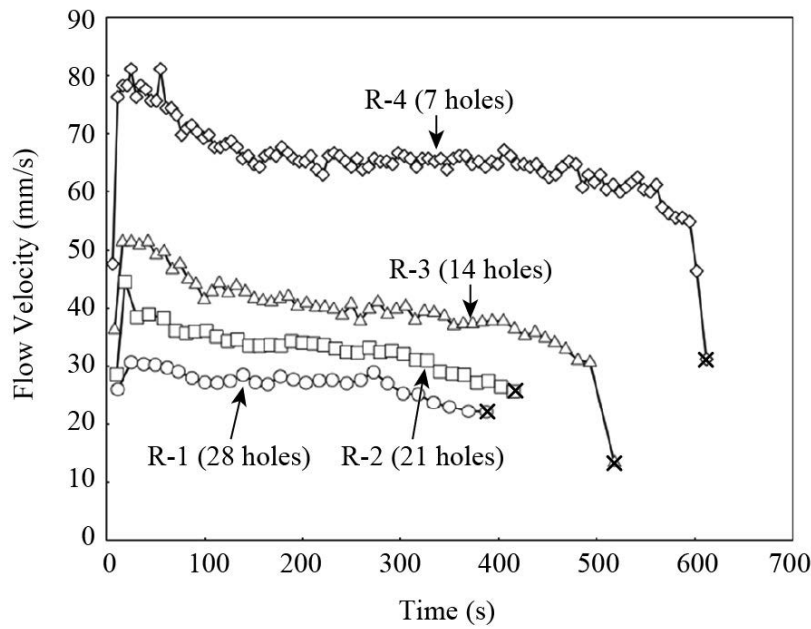

(b) Flow velocity

Fig. 2 Extrusion properties for raw spaghetti R-1, R-2, R-3 and $\mathrm{R}-4$. 
ダイス内面に負荷する圧力を測定した。ダイスに取り 付け用の孔を加工した様子は Fig. 1(d)に示したとおり である。なお，ダイスに取付け孔を設けたので 28 孔 (R-1) での圧力の測定は行えないため，21 孔（R-2), 14 孔（R-3），7 孔（R-4）の測定のみを行った。 パス タマシンはモータの駆動により振動しているため，測 定される押出し圧力も同等の周期で振動が生じてしま う。後に示す結果では，この振動の影響を考慮して 30 区間の移動平均を算出して押出し圧力とした。振動の ばらつきをともなうデータの処理に関して，1 本の線に 収束し，かつ元データのプロファイルをよく表してい たのが 30 区間であったので，本報では 30 区間の移動 平均を採用した。な拉，データのサンプリング周期は $0.1 \mathrm{~s}(10 \mathrm{~Hz})$ とした.

\section{2 表面および断面の観察}

表面と断面の観察は，日本電子(株)社製のフィールド エミッションタイプの走査型電子顕微鏡 (JSM-7001F) を用いた。開封直後の D-1，打よび押出し直後の R-1 の 2 種類をともに茹でる前の状態に対して，低倍率で は巨視的な表面性状の観察を行うため, スパゲティの 表面と断面を観察した。 D-1 と D-2，およびR-1〜 R-4 間で SEM 観察結果に大差がなかったため，素材情 報として代表的な D-1 と R-1 を比較した。また高倍率 では微視的なスパゲティ表面の小麦澱粉の観察を行い, 乾燥スパゲティと生スパゲティの比較を行った.

\section{3 含水率測定}

含水率の測定は, (株)島津製作所製の水分計 (MOC63u) を用いた. $130^{\circ} \mathrm{C} て ゙ ~ 1$ 時間の乾燥を行い, 乾燥前と乾燥 後の重量の差から含水率 $u$ を導出した. 水分の重量 $W_{\mathrm{W}}$, 乾燥後スパゲティの重量 $W_{\mathrm{S}}$ とすると, 重量基準 含水率 $u$ は式 (2)で表すことができる.

$$
u=\frac{W_{\mathrm{W}}}{W_{\mathrm{s}}+W_{\mathrm{W}}} \times 100
$$

含水率の測定は茹で前後の両方に対して行った。茹で 時間はメーカ推奨の乾燥スパゲティ $420 \mathrm{~s}$, 生スパゲ ティ $210 \mathrm{~s}$ とし, 食塩の添加によるスパゲティ物性に与 える影響を考慮して，食塩の添加は行わなかった [5].

\section{4 圧縮試験}

(株)東京試験機社製の卓上型小型万能試験機に，人が スパゲティを噛み切ることを模した角度 $91.04^{\circ}$ の樹脂 製の $\mathrm{V}$ 型プランジャーを製作して上部に装着し，下部 には平面の治具を取り付けて圧縮試験を行った。この

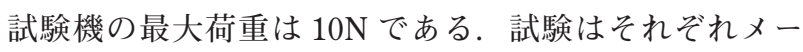
力推奨の時間で茹でた供試材 1 本に対して行い, クロ スヘッドのストロークは $1.0 \mathrm{~mm} / \mathrm{min} て ゙$ 常温大気中で 行った。この供試材 1 本の圧縮試験に先立って, 同条
件で数回の予備実験を行ったところ，同じ挙動を示し たことを確認した。試験機に取り付けたセンサユニッ トを介して，PCに試験中の時々刻々の荷重とストロー クのデータが保存される。なお，茹でた後の各供試材 は直径にばらつきがあるので，後述の実験結果では供 試材間の差異を比較しやすいよう，ストロークからひ ずみを算出し荷重 $P$ とひずみ $\varepsilon$ 関係として示した. 初期状態のスパゲティ直径を $D$, 変形後の直径を $d$ と して，ひずみ量 $\varepsilon の$ 導出は式 (3) を用いた. 式より，ス パゲティが破断して $d=0$ となるひずみ量 $\varepsilon=1.0$ では, 物理的に上部プランジャーが下部治具と接触したこと を示している。

$$
\varepsilon=\left|\frac{d-D}{D}\right|
$$

\section{3. 実験結果および考察}

\section{1 生スパゲティ作製時の押出し速度および圧力}

生スパゲティの供試材を作製したときの押出し圧力 の変化を Fig. 2 (a)に，押出し速度の変化の結果を同困 (b)に示す。両図に打ける $\times$ 印は 1 回分の生地の押出 しが終了したことを示している。この×印が押出しの 孔数が少ないほど右に位置していることから，押出し 孔数が少ないほど押出しに要する時間が長いことがわ かる．また，時間が経過するにつれて押出し速度，押 出し圧力ともに低下しているが，これは押出しが進む につれて混練した生地の量が減少したことが原因であ ると考えられる。四(b)に示した押出し速度は，孔の数 が少なくなるにつれて増加することが明らかである. これに対して, 図(a)の押出し圧力は R-2 と R-3 で同程 度であり，な执かつ $\mathrm{R}-4$ とも $1.0 \mathrm{MPa}$ 程度の圧力の差 でしかなかった. R-1， R-2， R-3， R-4ではダイスの 孔数がそれぞれ 28 孔，21 孔，14 孔，7 孔と異なるので, それに応じて押出し圧力が Fig. 2(a)のように変化し, 押出し速度もこれに併せて異なっている。 なお，ダイス 孔数が少ないと単位時間で押し出す量が少ないため，押 し出しが完了するまでの時間は長くなっている.

以上のように，押出し圧力に主立った変化はないが, 押出しの速度が顕著に変化した生スパゲティを，押出 し条件の異なるスパゲティとして供試材に用いた。後 の圧縮試験では，この押出し速度が安定した領域内か ら供試材を採取した。

\section{2 表面および断面}

乾燥スパゲティ D-1 扎よび，生スパゲティ R-1の断 面と表面の走査型電子顕微鏡写真を Fig. 3 に示す. 図 (a) の断面写真では，乾燥スパゲティ D-1に矢印で示した き裂が観察された。これはスパゲティ製造段階での乾 燥工程で生じたものか，あるいは後述するように，D-1 


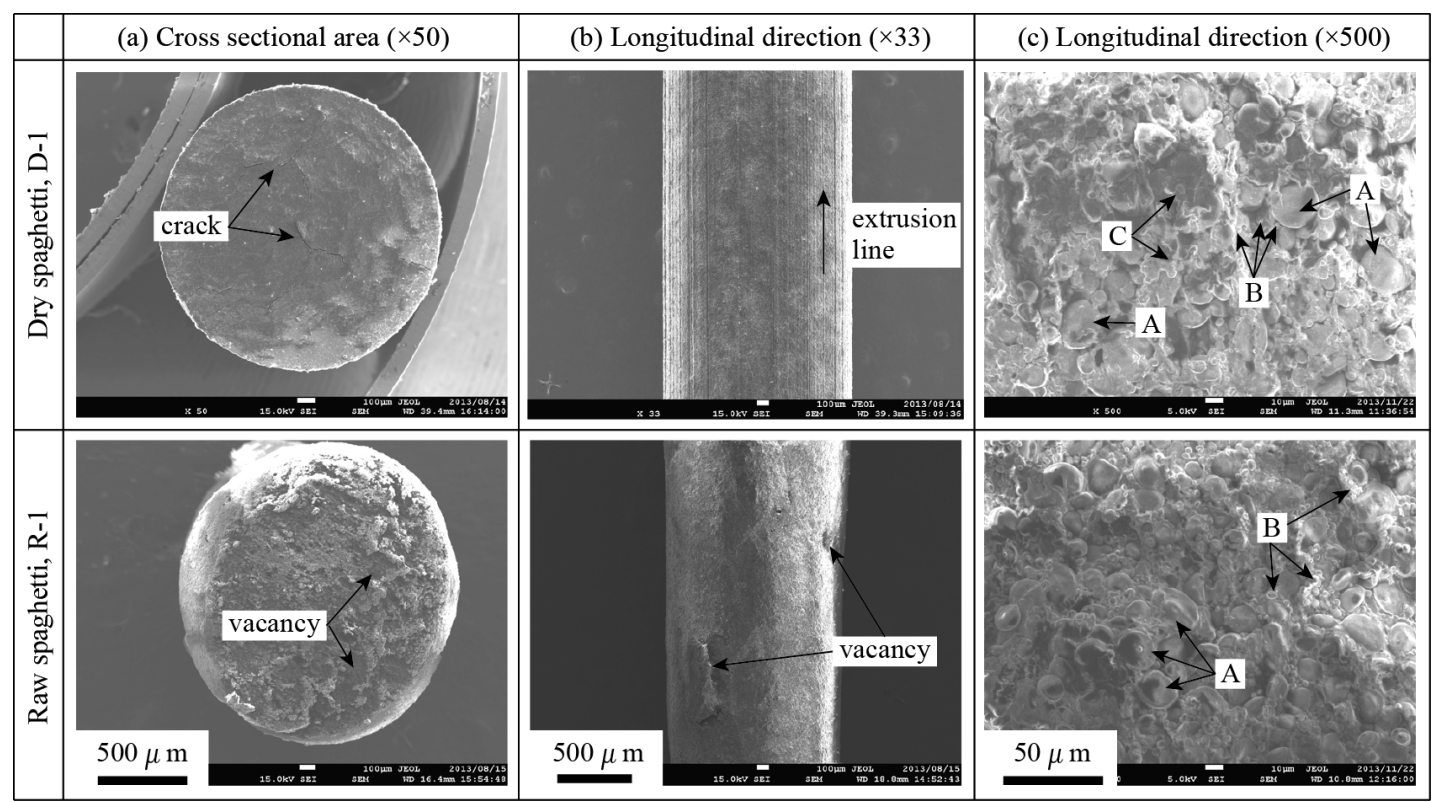

Fig. 3 Scanning electron microscopies for cross sectional area and longitudinal direction of dry spaghetti D-1 and raw spaghetti $\mathrm{R}-1$.

は $7.2 \%$ と低い含水率のため，走査型電子顕微鏡内で真 空状態にした時にできたヒビかは不明である。生スパ ゲティ R-1に，乾燥スパゲティ D-1で確認されない空 洞が多数確認できた。この空洞は生スパゲティの混捏 時に機械が巻き込んだ空気が原因となっている可能性 がある。罒(b)の長手方向表面の観察結果では，D-1に は押出し方向にはっきりとした線がみられた。これは 製造工場で押出し加工された時のダイス孔内側の表面 粗さ性状が転写されたものである。これに対して，R-1 には線はみられなかったが，空洞が多く存在した。こ れはパスタマシンでデュラムセモリナ粉と軟水を自動 混練した際の素材の粗密さに起因すると考えられる. これら麺全体の表面性状の違いが，食感や舌触り，さ らにはソースの絡まり具合に影響を及ぼすことは明ら かである.

続いて高倍率での長手方向表面の走査型電子顕微鏡 写真を同図 (c) に示す. D-1 および R-1 の両者に，直径 約 15 20 $\mu \mathrm{m}$ の大粒澱粉（図中 A）と約 $5 \mu \mathrm{m}$ 以下の小 粒澱粉（四中 B) が観察された [6]。それぞれの粒径は D-1，R-1 間で大差はなかった。また，D-1に执いては 粒状を呈していない老化澱粉と考えられる澱粉（図中 C）が確認された。一般に澱粉の状態は 3 種類に分類さ れ，1つはきれいな粒状を保っている「澱粉」，1つは 澱粉に水分と熱が加わり，いわいる糊の状態となった やわらかい「糊化澱粉」, 残る 1 つは糊化澱粉が常温で 時間経過し硬く変質した「老化澱粉」である.したがっ て，乾燥スパゲティの製造段階の乾燥工程で，水分を 含んだスパゲティが高温乾燥されることによって糊化 澱粉となり，その後常温に戻り時間経過することで糊
化澱粉が硬い老化澱粉へ変質したと推察される [6], [7].

\section{3 含水率}

茹でる前および茹でた後の各スパゲティの含水率の 測定結果を Fig. 4 に示す。茹でる前の乾燥スパゲティ については，D-2 の含水率が D-1の含水率を下回った ことから，乾燥スパゲティでは開封期間が長くなると 含水率が低下する傾向が認められた。茹でる前の生ス パゲティについては 4 種類全てに打いて，製造時に同 量のミネラルウォータを添加していることから同程度 の含水率となった。 また，茹でる前の乾燥スパゲティ と生スパゲティを比較すると，容易に想像できるとお

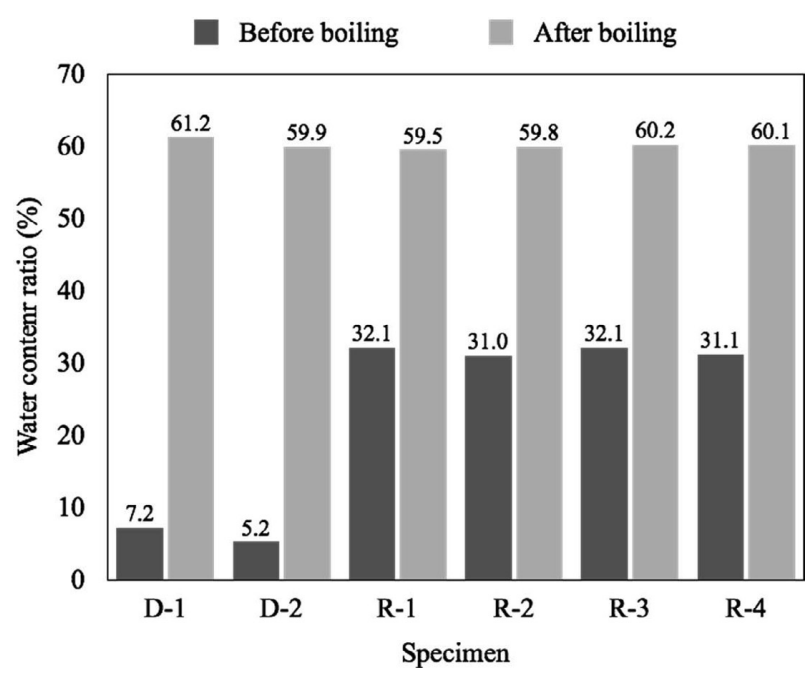

Fig. 4 Changes for the water content ratio. 
り，生スパゲティの含水率は乾燥スパゲティのそれを 大きく上回る結果となった，以上のように，茹でる前 では乾燥スパゲティと生スパゲティ間で大きな差異が あったが，茹でた後のスパゲティを比較すると全てに 扎いて約 $60 \%$ の含水率であり，どちらのスパゲティで も食す際は同等の含水率を有していることが明らかに なった。このことは, 圧縮試験から得られた結果で食 感の違いを評価するにあたって，含水率は無関係と考 えることができることを意味する。

\section{4 圧縮試験}

圧縮試験はスパゲティを噛んだ時の変形抵抗を示す もので，ここから得られる最大荷重や変位量といった 機械的特性值は，直接的にスパゲティの食感を評価す る指標として信頼のある值となる。茹でた乾燥スパゲ ティおよび生スパゲティに対する圧縮試験の結果を Fig. 5 に示す。食品を対象とした圧縮試験の結果は，荷 重とクロスへッドストローク (変位) の関係でまとめ られるが一般的であるが，直径の異なるスパゲティに 対する試験結果を相対的に評価するために，先の式 (3) で直径からひずみ量を算出し, これを図の横軸とした. 乾燥スパゲティの D-1，D-2の結果に関して，著しい 差異はみられなかった。言い換えれば, 乾燥スパゲティ は開封後 16 ヶ月が経過しても開封直後と同様の品質が 担保されていることがわかる. 同様に生スパゲティの $\mathrm{R}-2 ， \mathrm{R}-3 ， \mathrm{R}-4$ 間にも差異はなかった。 これらのこと から，今回調査した範囲内では，乾燥スパゲティの開 封期間と生スパゲティの押出し条件は，スパゲティの食 感に影響を与える因子ではないということが明らかに なった。

乾燥スパゲティと生スパゲティの結果を比較すると, 最大荷重はいずれも $P=0.5 \sim 0.6 \mathrm{~N}$ で同程度の值となっ たが，最大荷重時のひずみ量と破断時のひずみ量に顕

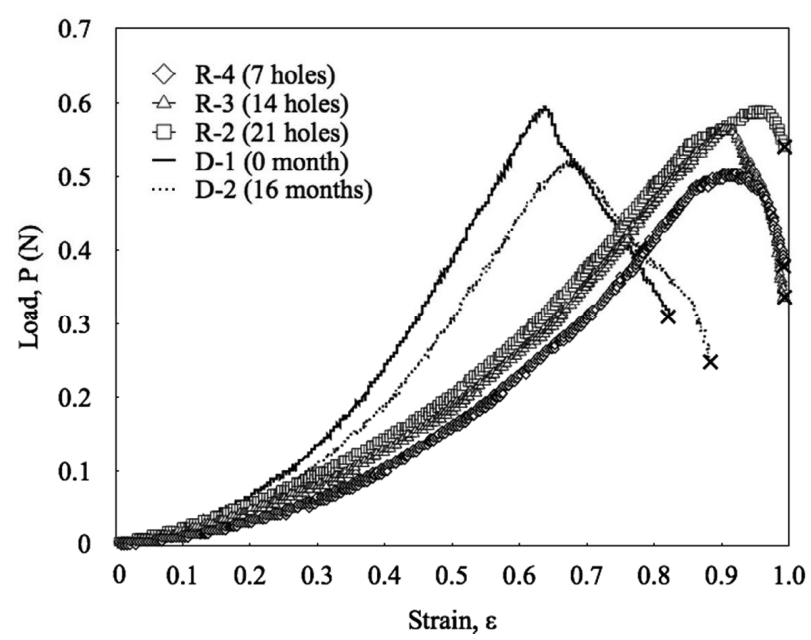

Fig. 5 Results of compression test for the boiled spaghetti.
著な差異が確認された。乾燥スパゲティでは最大荷重 でのひずみ量が $\varepsilon \fallingdotseq 0.6 \sim 0.7$ ，破断時のひずみ量が $\varepsilon \fallingdotseq$ 0.8 であったのに対し，生スパゲティの最大荷重に対応 するひずみ量が $\varepsilon \fallingdotseq 0.9$, 破断に対応するひずみ量は $\varepsilon$ $\fallingdotseq 1.0$ であった。 この最大荷重に達したときのひずみ量 と破断時のひずみ量は食感と強い関係があると考えら れる. 先述のとおり，ひずみ量 $\varepsilon=1.0$ で物理的に上部 プランジャーと下部治具が接触したことを意味するの で，圧縮試験の結果で破断点が $\varepsilon=1.0$ に近いほど破断 が生じにくく粘性の高い麺であることがわかる。これ と逆に， $\varepsilon=1.0$ より小さいほど，麺は脆性的に破断し ていることが明らかである。また，最大荷重に達する までの荷重一ひずみ線困の傾きが小さいこと，すなわ ち最大荷重に達するまでのひずみ量が多いことは，麺 の食感を表現する「モチモチ」や「コシがある」とい われる状態が長時間続くことに対応する [7]. 本実験の 結果では，乾燥スパゲティ D-1, D-2よりも生スパゲ ティ R-2， R-3， R-4の方が最大荷重に達するまでのひ ずみ量が多いので，「モチモチ」や「コシがある」食感 が長続きすることが実証されたことになる。このこと は，乾燥スパゲティよりも生スパゲティの方が「モチ モチ」していると，一般的に評される結果と対応して いる.

\section{5 スパゲティの性質に影響を与える因子の検討}

開封時期が異なる乾燥スパゲティ 2 種類, 押出し条 件が異なる生スパゲティ 4 種類に対して，走査型電子 顕微鏡による表面および断面の観察，茹で前後での含 水率測定，プランジャーを用いた圧縮試験，のそれぞ れの試験を行った．乾燥スパゲティ D-1と D-2 の間に 打いて, 開封から期間が経過すると乾麺の状態での含 水率が低下する傾向が確認された。 しかしその他の試 験結果に打いては, 開封時期が異なる乾燥スパゲティ 間，押出し条件が異なる生スパゲティ間に大差はなかっ た。これらのことから，乾燥スパゲティの開封期間や 生スパゲティの押出し条件は, スパゲティの品質や食 感に影響を与える重要な因子ではないことが明らかに なった。

一方，乾燥スパゲティと生スパゲティ間では含水率 測定でも著しい差異はなかったことから，乾燥スパゲ ティ, 生スパゲティともに同程度の含水率のスパゲティ であるといえる。この同程度の含水率を有する乾燥ス パゲティと生スパゲティ間で表面技よび断面の観察, そして圧縮試験において明らかな差異が確認された。 これらの差異が生じた原因として 2 つ要因が考えら れる. 1 つ目に高倍率での表面観察結果で示した澱粉の 変質である。一般的に澱粉は一度老化澱粉になると元 の糊化澱粉に戻すことは非常に難しい，スパゲティを 茹でたとき，生スパゲティはその大半が糊化澱粉にな 
るのに対して, 老化澱粉が多く含まれた乾燥スパゲティ は茹でても全てが糊化澱粉にはならない，老化澱粉は 糊化澱粉より粘度が低い性質をもつため [8], 圧縮試験 では乾燥スパゲティが $\varepsilon \fallingdotseq 0.8$ 程度で早期に脆性的に破 断したと推測される。

2 つ目として, 乾燥スパゲティを茹でた際は「アルデ ンテ」とよばれる状態で芯が残ることが知られている が，これに関連するものである。乾燥スパゲティを茹 でる際，スパゲティを茹でる前にもつ含水率とスパゲ ティ表面から中心部へと打湯が浸潤していく浸透率の 関係から，乾燥スパゲティは芯が残り生スパゲティに は芯は残らない，乾燥スパゲティに「アルデンテ」の 芯が存在することが，圧縮試験において最大荷重が生 スパゲティと同等程度になる要因になっていることも 事実ではあるが，芯が断面中心に存在するため最大荷 重に達するのが生スパゲティよりも早期であったとも 考えられる。

以上のように，乾燥スパゲティの高温乾燥工程によ り澱粉が老化澱粉へと変質したこと，ならびに物理的 に乾燥スパゲティに「アルデンテ」の芯が残存すること, の両点がスパゲティの食感に大きな影響を与えている と考えられる. 芯の残存は乾燥スパゲティでは避け得 ないことであるが，澱粉の変質は製造時の乾燥条件に 大きく依存する。したがって，スパゲティの品質や食 感に最も影響を与える因子は，本報の範囲内では乾燥 条件であると考える。

\section{4. 結言}

本報では，スパゲティの品質に影響を与える因子を 調査するため，製造条件の異なる乾燥スパゲティおよ び生スパゲティに対して，走査型電子顕微鏡による表 面扎よび断面の観察，茹で前後での含水率測定，プラ ンジャーを用いた压縮試験をそれぞれ実施した。得ら れた主な結果は以下のと打りである。

（1）含水率測定の結果から，全ての乾燥スパゲティ, 生スパゲティは茹でた後に約 $60 \%$ の一定の含水率を有 していることがわかった。これは，食感の違いを評価 するにあたり，含水率は一定として考えることができ ることを意味する。

（2）圧縮試験の結果から，今回調査した範囲内では, 乾燥スパゲティの開封期間や生スパゲティの押出し条 件は，スパゲティの品質に影響を与える重要な因子で はないことが明らかになった。

（3）圧縮試験の結果から，乾燥スパゲティよりも生ス パゲティの方が最大荷重に達するまでのひずみ量が多 いので，一般的にいわれる「モチモチ」，「コシがある」 という食感を有していることを実験により実証した。

（4）総合的な実験結果の考察から，乾燥スパゲティの
高温乾燥工程により澱粉が老化澱粉へと変質したこと, ならびに物理的に乾燥スパゲティに「アルデンテ」の 芯が残存すること，の両点がスパゲティの食感に大き な影響を与えていると考えられる。

\section{引 用 文 献}

1) A. Baiano, A. Conte, M. A. Del Nobile; Influence of drying temperature on the spaghetti cooking quality", J. Food Eng., 76, 341-347 (2006).

2) H. Shibasaki; "The Effect of the Number of "Fukugou (Folding of Dough-sheet)" on the Quality of "Tenobesomen (Hand-extended Noodles)"”, (in Japanese), Report of the Food Research Institute and the Fermentation \& Food Experimental Station, Kagawa Prefectural Government, 85, 6-12 (1993).

3) K. Okada, T. Ichikawa, M. Shimomura; "Effect of Starches and Active Gluten Added to Wheat Flour on the Properties and Taste of Japanese Hand-made Noodle”, (in Japanese), J. Cookery Sci. Jpn., 41, 327-336 (2008).

4) S. Chillo, M. Iannetti, V. Civica, N. Suriano, M. Mastromatteo, M. A. Del Nobile; A study of the Relationship between the Mechanical Properties and the Sensorial Optimal Cooking Time of Spaghetti”, J. Food Eng., 94, 222226 (2009).

5) S. Tesaki, S. Tanabe, K. Ikezaki, E. Arai, M. Watanabe; "Effect of stirring and added salt during boiling on the properties of cooked noodles" (in Japanese), J. Home Econo. Jpn., 48, 12, 1097-1101 (1997).

6) M. Kojima, M. Murase, S. Totani, M. Sugimoto; “Scanning electron microscopy of hand-streched noodles (tenobemen) and machine-made noodles (kikai-men)" (in Japanese), J. Japanese Soc. for Food Sci. and Tech., 39, 471476 (1992).

7) E. Miki; "Texture of udon" (in Japanese), J. Japanese Soc. Bio., 20, 32-39 (2006).

8) A. Matsunaga, K. Kainuma; "Studies on the retrogradation of starchy food (part 1)” (in Japanese), J. Home Econo. Jpn., 32, 653-659 (1981).

要旨

本報では，製造条件の異なる数種類のスパゲティを 対象として，機械的性質の観点から茹でた後の特性值 の違いを実験的に調查した。また，乾燥スパゲティと 生スパゲティの機械的な特性值を，含水率や電子顕微 鏡による表面観察結果と総合して評価し，スパゲティ の品質に影響を与える因子について考察した。

その結果, 乾燥スパゲティの高温乾燥工程により澱 
粉が老化澱粉へと変質したこと，ならびに物理的に乾 存する.したがって，スパゲティの品質や食感に最も 燥スパゲティに「アルデンテ」の芯が残存すること，影響を与える因子は，本報の範囲内では乾燥条件であ の両点がスパゲティの食感に大きな影響を与えている ると考えた.

ことがわかった。芯の残存は乾燥スパゲティでは避け 今回のこれらの調査結果は, 今後のスパゲティ麺の 得ないが，澱粉の変質は製造時の乾燥条件に大きく依＼cjkstart食感向上に設計指針として役立つと考えられる. 